\title{
Goitrogenic Effects Of Mustard Seed (Bassica Junca) Oils
}

\author{
Aloh Godwin Sunday ${ }^{1 *}$, Emmanuel Ifeanyi Obeagu ${ }^{2}$ And Omeh Yusuf \\ Ndukaku ${ }^{1,}$ \\ 1.Lecturer, Department of Biochemistry, Michael Okpara University of Agriculture, Umudike, Abia State, \\ Nigeria. \\ 2.Diagnostic Laboratory Unit, University Health Services Department, Michael Okpara University of \\ Agriculture, Umudike, Abia State, Nigeria.
}

\begin{abstract}
The goitrogenic effects of commercial mustard seed aws studied when the oil was fed to rabbits.A toatl of 9 rabbits divided into 3 groups of 3 rabbits each was used in the study.Those in group A were given $5 \mathrm{ml}$ of the mustard oil per $\mathrm{kg}$ body weight 3 times daily, those in group B were given 10ml per kg body weight 3 times daily while those in group $C$ were not given the oil at all and served as control.The mustard seed oil was fed in a total of 4 days.The mean values of the protein-bound iodine of groupA rabbit were 0.25ug/dl+/-0.13(an increase of $45 \%), 0.58 \mathrm{ug} / \mathrm{dl}+/-0.24$ (an increase of $61.10 \%$ ) and $1.00 \mathrm{ug} / \mathrm{dl}+/-0.33$ (an increase of $72.24 \%$ ) from day 1 to day 4 respectively.In group B animals, the protein-bound iodine levels were 0.23ug/dl+/-0.32(an increase of 74.55\%), $1.78 \mathrm{ug} / \mathrm{dl}+/-0.32$ (an increase of $85 \%$ ) and $3.51 \mathrm{ug} / \mathrm{dl}+/-0.47$ (an increase of $95 \%$ ) from day 1 to day 4 respectively. The levels seen in group $A$ and $B$ showed dose-dependence.In both groups, significant daily increase in protein bound-iodine were observed and ranged from $45-72.24 \%$ in group $A$ in 4 days and 74.55- 95\% in group B for the same period.Group C animals had fairly constant protein-bound iodine levels within the study period because they did not receive the mustard seed oil at all. Selective phytochemical anlysis revealed the presence of many known goitrogens-flavonoids,phenolic compounds, tannins, alkaloids but not anthraquinones.This could explain the elevation of protein-bound iodine levels in these animals within a few days.

Keywords: Goitrogenic effects, Iodine, Mustard seeds oil and Anthraquinones.
\end{abstract}

\section{Introduction}

The use of medicinal plants in the treatment of diseases and in use as food condiments have been in practice since the ancient time in different part of the world especially in Africa. Over 10,000 medicinal plants exist in West Africa which are used in disease treatment and prevention (Rosengarten, 1989). According to (John, 1984), the history of medicinal plants in Africa is part of human history. Thousands of plant species grow wild all over the world and have served both nutritional and therapeutic purposes (John, 1984). Some examples of medicinal plants include Alstonia boonei used in the treatment of asthma, the seed of Syzgium cumin is used to manage diabetes in India, Chromoleama odorata and the leaves of Carica papaya is used to treat wounds.

The mustard seed is a well known oil seed. It is a small annual plant which grows up to a height of 1 meter with some branches (John, 1984). Mustard seed oil has been found to obtain important phytochemicals like tannins, alkaloids. And flavonoids (Rosengarten,1989). Mustard seed oil had been used successfully both for medicinal used and as food spice.

Goitrogens are foods or substances which suppress thyroid function. A number of compounds have the ability to inhibit thyroid hormone synthesis. Irrespective of the mechanism of action of these goitrogens they result in the decrease in serum thyroid hormone level. Both iodine deficiency and inability to use iodine properly make the thyroid gland unable to produce thyroid hormone (Osman, 1981). There are many medicinal uses of mustard seed oil but it is known to contain chemicals, mainly secondary metabolites such as flavonoids, tannins, alkaloids and glycosides. Some of these are known to impair thyroid function.

In this work therefore, the commercial mustard seed oil fed to the rabbits will be screened for the presence of these metabolites and the thyroid function of these rabbit assesses by measuring the levels of protein bound iodine.

In recent times, I have noticed in public places like churches and markets where mustard seed oil and mustard seed are being advertised and sold to members of the public. It is acclaimed that these mustard seed and oil when taken, can cure a number of ailments including GOITRE, the essence of this project is to ascertain how true this claim is. It is intended to identify the goitrogens in mustard seed oil and assess its effect on plasma bound protein in rats fed with the oil. 


\section{Material/Methods}

.COLLECTION OF MUSTARD OIL

The commercial bottled mustard oil was obtained from the Onitsha main market.

\section{ANIMALS}

A total of 9 rabbits were bought from the Ogbete main market of Enugu State, Nigeria. The rabbits were then kept for acclimatization at ordinary Laboratory conditions for 3 days. The animals were grouped into 3 of $\mathrm{A}, \mathrm{B}, \mathrm{C}$ of 3 rabbits each.

\section{MEASUREMENT OF THE WEIGHT OF THE ANIMALS}

The weights of the animals were measured throughout the period of the study.

\section{ADMINISTRATION OF THE MUSTARD OIL TO THE ANIMALS}

The animals in group A were given $5 \mathrm{ml}$ per $\mathrm{kg}$ body weight of the mustard oil while those on group B were given $10 \mathrm{ml}$ per $\mathrm{kg}$ weight of the mustard oil 3 times daily. Animal in group $\mathrm{C}$ served as the control and were not given the mustard oil and thus maintained their normal ration of food and water only. The administration of the mustard oil was done through the oral route.

\section{PREPARATION OF REAGENTS}

The reagents used for the study were prepared as follows:

Wagner's reagent was prepared by dissolving $1.27 \mathrm{~g}$ of iodine and $2 \mathrm{~g}$ of Potassium iodide in $100 \mathrm{ml}$ of distilled water.

Mayer's reagent was made by dissolving $1.5 \mathrm{~g}$ of mercuric iodide and $5 \mathrm{~g}$ of Potassium iodide in $100 \mathrm{ml}$ of distilled water.

\section{REAGENTS USED TO IDENTIFY PHENOLIC COMPOUNDS}

Ferric chloride - Potassium ferricyanide reagent was prepared by mixing equal volumes of $0.1 \%(\mathrm{w} / \mathrm{v})$ Ferric chloride in water in $0.1(\mathrm{w} / \mathrm{v})$ Potassium ferricyanide in water.

Arsenious acid reagent was prepared by dissolving $0.19 \mathrm{~g}$ of Arsenic trioxide in $2 \mathrm{ml}$ of $0.5 \mathrm{M}$ of $\mathrm{NaOH}$. $150 \mathrm{ml}$ of deionised water was then added followed by the addition of $4 \mathrm{ml}$ of concentrated $\mathrm{H}_{2} \mathrm{SO}_{4}$. The solution was then cooled and diluted to $200 \mathrm{ml}$ which deionised water and then thoroughly mixed. $4.86 \mathrm{ml}$ of $\mathrm{H}_{2} \mathrm{SO}_{4}$ was added to $60 \mathrm{ml}$ of deionised water. $2 \mathrm{~g}$ of Ceric ammonium sulphate was added to the hot acid solution. The solution was then cooled and diluted to $100 \mathrm{ml}$. Stock iodide standard $-0.01 \mathrm{~g}$ of desiccator dried Potassium iodide was dissolved in $100 \mathrm{ml}$ of deionised water.

\section{BLOOD SAMPLE COLLECTION}

$2 \mathrm{ml}$ of blood was collected from each animal by venopuncture and the blood samples were centrifuged at low speed to obtain the plasma used for the work and stored in the refrigerator for later use.

\section{PHYTOCHEMICAL ANALYSIS}

Selected phytochemical analyses of the purified mustard seed oil were carried out according to the methods of Hambone (1973) and Iwu (1978).

The following specific tests were done.

\section{TEST FOR ALKALOIDS}

$1 \mathrm{ml}$ of the mustard oil was boiled with $6 \mathrm{ml}$ dilute hydrochloric acid, filtered and cooled. The filtrate was divided into 2 portions and the following further test performed.

To one portion was added 2 drops of Mayer's reagent.To the Second portion was added 2 drops of Wagner's reagent. Formation of precipitate indicates the presence of an alkaloid in either case.

\section{TEST FOR TANNINS}

$1 \mathrm{ml}$ of the mustard oil was shaken with $1 \mathrm{ml}$ of distilled water, filtered and 2 drops of Ferric chloride reagent added to the filtrate. The appearance of a precipitate indicate the presence of tannins

\section{TEST FOR ANTHRAQUINONES}

$1 \mathrm{ml}$ of mustard oil was boiled for 3 minutes with $6 \mathrm{ml}$ of Dilute Sulphuric acid, cooled and filtered. The filtrate was shaken with $4 \mathrm{ml}$ of ether, $1 \mathrm{ml}$ of ammonia solution was added. Absence of 2 Layers of solution lower yellow and upper coloured layer indicates absence of anthraquinone. 


\section{TEST FOR FLAVONOIDS}

$1 \mathrm{ml}$ of the mustard oil was boiled with $3 \mathrm{ml}$ of Ethyl acetate, filtered and cooled. The filtrate was shaken with $1 \mathrm{ml}$ of dilute ammonia solution. A yellow colour in the ammonia layer indicates the presence of flavonoids.

\section{TEST FOR GLYCOSIDES}

Into a $2 \mathrm{ml}$ solution of the mustard oil in $3 \mathrm{ml}$ of Ethyl acetate was added 2 drops of alpha - napththol. $1 \mathrm{ml}$ of concentrated sulphuric acid was carefully poured down the side of the tube so as to form 2 layers. Presence of a purple ring at the junction ofthe 2 layers indicates the presence of glycosides.

\section{PROTEIN - BOUND IODINE ASSAY}

To $1.0 \mathrm{ml}$ of plasma from each rat $\mathrm{n}$ separate test tubes were added $7.0 \mathrm{ml}$ deionised water. $1.0 \mathrm{ml} \mathrm{ZnSO}_{4}$ reagent and $1.0 \mathrm{ml}$ of $0.5 \mathrm{M}$ of $\mathrm{NaOH}$, in that order and mixed thoroughly with a glass stirring rod. The mixture was then centrifuged for 10 minutes at 3000 r.p.m. the supernatant solution was decanted and the protein precipitate was washed by re-suspending it in $5.0 \mathrm{ml}$ of deionised water. This was again centrifuged and the supernatant decanted. The washing was repeated two times. To the tube containing the washed protein precipitate, the following were added;- $0.5 \mathrm{ml} 2 \mathrm{M}$ Sodium carbonate $-2 \%$ Potassium chlorate solution. The tubes were left overnight in the oven at $110^{\circ} \mathrm{C}$. The dried precipitate was then incinerated in the oven at $620^{\circ} \mathrm{C}$ after which the tubes containing the precipitate were allowed to cool. $10 \mathrm{ml}$ arsenious acid was added to each tube to dissolve the ash. After allowing the tubes to leach for 15 minutes with occasional shaking, they were then centrifuged for 20 minutes at 3000 r.p.m. 5.0ml of the dissolved ash - arsenious acid solution was transferred to clean tubes. The tubes were mixed thoroughly by shaking after which they were returned to the water bath. Exactly 20 minutes after the addition of Ceric $\mathrm{nm}$ was read against ammonium sulphate, the absorbance of the solution at $420 \mathrm{~nm}$ was read against a distilled water blank. This procedure was repeated for each plama sample.

\section{PREPARATION OF STANDARD CURVE}

To a set of 5 test tubes were each added $1.0 \mathrm{ml}$ of working iodide standards with concentrations of 0.04 , $0.08,0.12,0.16$ and $0.20 \mu \mathrm{g}$ iodide/ $\mathrm{ml}$ respectively. The tubes were placed at $100^{\circ} \mathrm{C}$ in a drying oven and left overnight. Arsenious acid reagent $(10 \mathrm{ml})$ was added to each of the tubes and the tubes were swirled round carefully to ensure through leaching out of the iodide present. The tubes were then centrifuged for 20 minutes. $5.0 \mathrm{ml}$ each of the resulting solution was transferred to clean tubes. The tubes were then placed in a $37^{\circ} \mathrm{C}$ water bath for 15 minutes. $1.0 \mathrm{ml}$ Ceric ammonium sulphate reagent was added to each tube, the contents mixed thoroughly by vigorous shaking and the tubes returned to the water bath. Exactly 20 minutes after the addition of ceric ammonium sulphate, the absorbance at $420 \mathrm{~nm}$ was read against a distilled water blank. A standard curve was prepared by plotting the absorbance readings against the iodide concentrations of $4,8,12,16, \mathrm{mg}$ iodide standards of $0.04,0.08,0.12,0.16$ and $0.20 \mu \mathrm{g}$ iodide $/ \mathrm{ml}$.

A smooth curve was drawn through the points and the protein bound iodine content of the unknown was read from this curve.

\section{Results}

Table 1: The Results of the Phytochemical analyses are as follows:

\begin{tabular}{|l|l|}
\hline Phytochemical & Results \\
\hline Alkaloids & Positive \\
\hline Tannins & Positive \\
\hline Flavonoids & Positive \\
\hline Phenolic compounds & Positive \\
\hline Glycosides & Positive \\
\hline Anthraquinones & Negative \\
\hline
\end{tabular}

Table 1: Above reflects the results of the phytochemical analysis of the mustard seed oil. Alkanoids, Tannins, Flavonoids, Phenolic compounds and Glycocides which are secondary metabolites known to cause goitre. Anthraquinones were absent.

\section{Protein - Iodine Assay}

Table 2: Group A (Fed 3 times daily with $5 \mathrm{ml}$ of oil per kg body weight)

\begin{tabular}{|l|l|l|}
\hline Optical Density & Mean Concentration $(\mu \mathrm{g} / \mathrm{dl})$ & Percentage increase \\
\hline 0.15 & $0.25 \pm 0.13$ & - \\
\hline 0.22 & $0.36 \pm 0.17$ & $45 \%$ \\
\hline 0.35 & $0.58 \pm 0.17$ & $61.10 \%$ \\
\hline 0.60 & $1.00 \pm 0.33$ & $72.24 \%$ \\
\hline
\end{tabular}


The table 2: above shows the mean protein - bound iodine (PBI) levels of rat that received $5 \mathrm{ml}$ of the oil per $\mathrm{kg}$ body weight. Elevation of PBI levels of between $45-72 \%$ were recorded within 4 days of the mustard seed oil incorporation into the rat's diets.

Table 3: Group B (Fed 3 times daily with $10 \mathrm{ml}$ of oil per $\mathrm{kg}$ body weight).

\begin{tabular}{|l|l|l|}
\hline Optical Density & Mean concentration $(\mu \mathrm{g} / \mathrm{dl})$ & Percentage increase \\
\hline 0.12 & $0.23 \pm 0.32$ & - \\
\hline 0.23 & $0.96 \pm 0.48$ & 74.55 \\
\hline 0.44 & & \\
\hline 0.95 & $1.78 \pm 0.32$ & 85.00 \\
\hline
\end{tabular}

The table 3: above represents the mean PBI levels of the rats fed with $10 \mathrm{ml}$ of mustard seed oil per kg body weight. Elevations to between $74-95 \%$ were recorded within 4 days of mustard seed oil incorporation into their diets.

Table 4:Group C (Not fed with oil)

\begin{tabular}{|l|l|l|}
\hline Optical Density & Mean concentration $(\mu \mathrm{g} / \mathrm{dl})$ & Percentage increase \\
\hline 0.15 & $0.25 \pm 0.30$ & - \\
\hline 0.16 & $0.26 \pm 0.19$ & insignificant \\
\hline 0.14 & $0.24 \pm 0.41$ & Insignificant \\
\hline 0.16 & $0.26 \pm 0.22$ & insignificant \\
\hline
\end{tabular}

The table 4: shows the levels of the control group grats in which mustard seed oil was incorporated into diets. The charges in their PBI were insignificant.

\section{Discussion And Conclusion}

This work set out to investigate the presence of goitrogens in mustard seed oil and assess the effects of the oil on the thyroid function of rabbits fed with it. This arose from the claim that among many other ailments, mustard seed oil can cure goitre, a claim that is in conflict with a counter claim that it contains goitrogens.

Strikingly, of all the secondary plant metabolites known to cause goitre such as tannins, flavonoids and glycosides, anthraquinones were found to be absent in the oil when selective phytochemical screening was carried out on the oil. The effects of the oil on thyroid function were assessed by measuring the concentrations of plasma - bound iodine of the 3 groups of rabbits - those receiving $5 \mathrm{ml}$ and $10 \mathrm{ml}$ of the oil respectively per $\mathrm{kg}$ body weight, and the control group that was kept on oil - free diet for 4 days.

In group A animals fed with $5 \mathrm{ml}$ of the oil per kg body weight, the initial concentrations of protein bound iodine was $0.23 \mu \mathrm{g} / \mathrm{dl}$, but within the next 24 hours, the level had risen by $45 \%$ to $0.36 \mu \mathrm{g} / \mathrm{dl}$ and by $61.10 \%$ and $72.24 \%$ to $0.58 \mu \mathrm{g} / \mathrm{dl}$ and $1.00 \mu \mathrm{g} / \mathrm{dl}$ respectively in the next two days. The levels of plasma bound iodine stood at $0.55 \mu \mathrm{g} / \mathrm{dl}$ from $0.23 \mu \mathrm{g} / \mathrm{dl}$ within 24 hours of feeding the group B animals with $10 \mathrm{ml}$ of the oil per kg body weight. This was an increase of $139.13 \%$. by the second day, this level had risen to $0.36 \mu \mathrm{g} / \mathrm{dl}$, representing $75 \%$ rise in plasma level of plasma - bound iodine which rose further by $61.10 \%$ and $72.24 \%$ respectively in the next two days.

The initial sudden increase in the levels of protein - bound iodine suggest that there is an initial high uptake of iodine by plasma proteins, and that it progresses as more iodine is absorbed into the blood.

Since proteins are anionic (negatively charged) at physiological $\mathrm{pH}$, and metabolic iodine exists as an oxidized organic it appears most probable that the identified goitrogens in the oil posses groups that compete for, and displace this iodine from thyrosine. As free organic iodine, it is likely that it binds to the readily available proteins that bind and transport the thyronins-3,5,3,5-tetraiodothyronine $\left(\mathrm{T}_{4}\right)$ and 3,5,31triodothyronine $\left(\mathrm{T}_{4}\right)$ - the major and most active iodine-containing hormones, these thyronine bindingtransporting proteins are thyronine - binding globuline and thyronine - binding prealbumen and albumen. (Frissel, 1982). The increasing eivels of protein - binding iodine as mustard seed oil ingestion continued could therefore be explained by the fact that these protein biosynthesis.

The goitrogen - bound thyronines should be defective hormones and when delivered to the thyroid gland, cannot exert the proper hormonal effects of the normal thyronines. Deficiency therefore sets in and with prolonged ingestion of the oil the thyroid gland is bound to increase in size as it strives to perform its function in the face of low thyroxine level or in the abundance of defective (goitrogen - bound) hormone.

Since the oil used for this was imported from the United Arab Emirate, it is likely that the exclusion of the goitrogen was not important while extracting it from the seeds. Inspite of the much vaunted versatile 
therapeutic benefits of this oil as well as the reported abundance of vitamins and minerals in it, this work suggest that its consumption in high amounts could lead to thyroxine insufficiency and goitre.

\section{Conclusion}

In conclusion, selective phytochemical screening revealed goitrogens in the commercial-grade mustard seed oil used in the study, and which is freely sold to, and used by the public. Administration of $5 \mathrm{ml}-10 \mathrm{ml}$ per $\mathrm{kg}$ body weight elevated the levels of protein bound iodine, the major indicator for goitrogenesis, from $45 \%$ $95 \%$ in 4 days. The use of this oil in treating ailments should be discouraged unless one is certain that the identified goitrogens have been removed by further purification.

\section{References}

[1]. Anthony, S. F. (1997). Harrison's Principle of Internal Medicine. New York. Mc Graw-Hill, 5:7.

[2]. Bryan, J. (1996). Lloyds Survey Landwork, $2^{\text {nd }}$ Ed. 6 Aufi Laver - Hill, London. Pp. 753.

[3]. Cobran, R. S; Kumar, V. and Robbins, S. L. (1989). Robbins Pathologic Basis if Disease, $4^{\text {th }}$ Ed. W. B. Sauders and Co. Philadelphia. Pp. 227.

[4]. Derlin, T. M (2000). Biochemistry with Clinical Correlation. $5^{\text {th }}$ Edition. John Wiley and Sons.Inc. New York. Pp 8 - 13.

[5]. Ensminger, A. H; Ensminger M. F. and Kindale, J. E. (1986). Food and Nutrition Encyclopedia. Regus Press Cloris Carliforia.

[6]. Ensminger, A. H; Ensminger M. K. jetal. (1986). Food Health. A nutrition Enclopedia. Regus Press Cloris Carliforia.

[7]. Gaitan, E. (1988). Goitrogens. Baillietes Clin Endocrinol metabolism 2: 683 - 702.

[8]. Gaitan, M. A. (1990). Goitrogens in food and water. Annu. Rev. Nutr. 10: 21 - 39.

[9]. Gaitan, M. A. (1988). Modern Herbal. Dorer Publication New York.

[10]. Lagenbleek, Y; Lonypaert, B and De Nayer. P. (1980) Nutritional Status and Endemic goitre. Lancet 1: 388 - 391.

[11]. John L. (1984) the Herb book. $1^{\text {st }}$ Ed. Bantan books, New York, U.S.A 960Pp.

[12]. Kawada, J; Nishida, M; Yashimira Y. and Yamashita, K. (1985). Manganese ion as a goitrogen In the female mouse. Endocrinol Jpn. 32: $635-643$.

[13]. Koulras, D. A. Clin (1972). Iodine metabolism in endemic goiter. Ann. Clin. Res 4: 55 - 63.

[14]. Lambereg, B. A. C. (1991). Endemic goitre iodine deficiency disorders.

[15]. Ann. Med. 23: $367-392$.

[16]. Lambereg, B. A. C. (1993). Iodine deficiency deficiency disorders aid endemic goitre. Eur. J. Clin. Nutr. $47: 1$ - 8.

[17]. Malcom, S. (1987). The Encyclopaedia of herbs and herbalism. $1^{\text {st }}$ Ed. MacDonald and O., Turia, Italy. Pp 166.

[18]. Mutaku, J.F; Many, M.C and Colin, I (1998). Anbigoi trogenic effect of combined supplementation with di-alpha trocopherol, ascorbic acid and beta carolene and of di-alpha tocophenol alone in the rat. J. Endonnol. 156: $551-561$.

[19]. Osman, A. K; Fatch, A. A. (1981). Factors other thaniodine deficiency contributing to the Endonicity of goitre in Darfur province Sudan. J. Hum Nutr. 35: $302-309$.

[20]. Roengarten, F (Jr). (1989). The book of spices. $2^{\text {nd }}$ Ed. Livingstone publishing Co. Rem, USA. Pp 405.

[21]. Stoeward, G. S.(1995).bioactrine organosulfur phytochemicals in Brassics Oleracea Vegetables food, Chem.. Yonicol 23:537 543).

[22]. Wilson, J. O; Foster, O. W.; Gronenberg; H. M. and Larsen, P. R. (1998). Williams textbook Of Endo crimology. $9^{\text {th }}$ Ed. W. B. Sannders and Co. Philadelphia Pp 469. 